\title{
Case-control study of leatherwork and male infertility
}

\author{
J J Kurinczuk, M Clarke
}

\begin{abstract}
Objectives-To test the hypothesis that leatherwork is associated with male infertility mediated through the development of oligozoospermia. The basis of any association was postulated, at the outset, to be with exposure to the solvents used in leatherwork.
\end{abstract}

Methods-All new referrals with infertility presenting in Leicestershire hospital clinics between November 1988 and September 1992 and Kettering District General Hospital from August 1990 were eligible to participate; $88.5 \%$ agreed to be interviewed. Exposure to leatherwork and work with solvents was defined by job title. Comparisons were made with fertile controls and in an analysis within men from infertile couples with oligozoospermia as the primary outcome. Effects on sperm motility and deformity were investigated secondarily. Analyses used logistic regression for binary outcomes and multilevel modelling for continuous outcomes. Results-1906 men were interviewed. Compared with the fertile controls the men from infertile couples were 1.10 times (95\% confidence interval $(95 \% \mathrm{CI}) 0.46$ to 2.63; $p=0.99$ ) more likely to be leatherworkers and 1.73 times $(95 \%$ CI 1.26 to 2.38; $\mathrm{p}<0.001)$ more likely to work with solvents. Compared with other men, leatherworkers were 1.20 times $(95 \% \mathrm{CI}$ 0.43 to $3.33 ; p=0.73$ ) more likely to present with oligozoospermia and 1.65 times $(95 \%$ CI 0.37 to $7.30 ; p=0.51$ ) more likely to present with teratozoospermia. Being a leatherworker was associated with only a $6 \%$ reduction in sperm concentration; motility and deformity were similarly unaffected by this exposure. Work with solvents did not statistically, nor clinically, increase the risk of oligozoospermia, teratozoospermia, or asthenozoospermia.

Conclusions-There was little evidence to support the hypothesis that leatherwork is associated with an increased risk of presenting with infertility or oligozoospermia. There was limited evidence that leatherwork is a risk factor for teratozoospermia. Workers with solvents were at an increased risk of presenting with infertility, although this was not mediated through effects on standard measures of semen quality; this finding merits further investigation.

(Occup Environ Med 2001;58:217-224)

Dr J J Kurinczuk

jik6@le.ac.uk

Accepted 14 November 2000
Leatherwork has been implicated as a risk factor for several diseases. These include nasal, paranasal, bladder, lung, and testicular cancers. ${ }^{1-6}$ There is also some evidence of an association between leatherwork and haematopoietic malignancies, although this is thought to be related to exposure to solvents rather than leather itself. ${ }^{7-9}$ Several adverse reproductive outcomes associated with maternal exposure to leatherwork have been described and include an increased risk of perinatal death, reduced female fertility, spontaneous abortion, preterm delivery, low birth weight, and cleft palate. ${ }^{10-18}$ These reports include two that describe the relation between leatherwork and reproductive outcome in Leicestershire. ${ }^{10} 13$ However, the effects of exposure to leatherwork on male reproductive function, other than testicular cancer, have not been described.

In 1988 a Leicestershire gynaecologist reported a cluster of five men who worked in the Leicestershire boot and shoe industry who had attended his clinic with their wives complaining of difficulty conceiving; subsequent semen analysis showed them to have oligozoospermia (R Graham, personal communication). The aim of this study was to test the hypothesis that leatherwork is associated with male infertility mediated through the development of oligozoospermia. The basis of any association was thought, at the outset, to be exposure to the solvents used in leatherwork, rather than exposure to the leather itself or to leather substitutes.

\section{Methods}

Leicestershire is a county in central England with a population in excess of 860000 . All couples complaining of infertility and presenting as new referrals to any general gynaecological or specialist infertility clinic in Leicestershire between November 1988 and September 1992 inclusive were eligible and were invited to participate. A few Leicestershire residents who had been referred to hospitals outside Leicestershire were also identified and approached. Despite a high response to the study, recruitment did not meet the required target and therefore new patients referred with infertility to Kettering District General Hospital, Northamptonshire, were also included from August 1990 to September 1992. Northamptonshire is a county adjacent to Leicestershire and, like Leicestershire, it had an active boot and shoe industry. The only infertility specialist at the Kettering Hospital sees all referrals with infertility.

The study had the approval of the Leicestershire District Health Authority Ethics Com- 
mittees. All participants gave verbal informed consent.

\section{DATA COLLECTION}

The data were collected with a structured questionnaire administered by an interviewer. Both members of each couple were interviewed separately at the clinic. However, for the purposes of the results reported here only data from the interviews with male partners were used. Home interviews were conducted when patients were missed at the clinic. The questionnaire was designed to collect demographic and personal details, detailed occupational history, general medical and lifestyle information, and reproductive history. The results of routine semen analyses performed for clinical indications were obtained from the microbiology laboratories of the Leicester Royal Infirmary (the only testing laboratory in Leicestershire at that time) and Kettering District General Hospital. Semen analysis was carried out in both laboratories in accordance with the World Health Organisation guidelines. ${ }^{19}$

\section{EXPOSURE DEFINITION}

The two exposures of interest were leatherwork defined as a binary term (yes or no) and any occupations which involved work with solvents, similarly defined (yes or no). These were derived from the reported occupations that were coded with the 1970 and 1980 Office of Population Censuses and Surveys classification of occupation. ${ }^{2021}$ Leatherwork has a series of exclusive codes within each classification and was therefore straightforward to define. Jobs involving work with solvents were defined at the outset by reference to the occupational literature. The jobs and their codes included in both groups are given as an appendix, this list includes only those occupations experienced by the study participants.

CASE-CONTROL COMPARISONS

Two sets of case-control comparisons were carried out. The first comparisons used men from couples presenting with infertility resident in Leicestershire who were defined as the cases (Kettering patients and other couples living outside Leicestershire were excluded). The controls for this set of comparisons were the fathers of the control birth population from the Leicestershire perinatal mortality case-control study born 1985-92 inclusive. ${ }^{22}{ }^{23}$ The perinatal mortality study, which started in 1976 , is an ongoing population based case-control study of all perinatal deaths to Leicestershire residents. The controls are a robust representative sample of all Leicestershire births. ${ }^{22}$ The control exposure information used in the comparison for the study reported here was derived from the parental details recorded in the perinatal study. The details collected about the father in the perinatal study were limited to current occupational details only and were collected from the mother. Thus, confounder data were not available and could not be adjusted for in this part of the analysis.
The second set of comparisons was based on an analysis within the men of couples presenting with infertility. That is, all the men from infertile couples with semen results were divided, on the basis of the results of the semen analysis, into cases who had oligozoospermia and controls who did not. Oligozoospermia was defined as a sperm concentration of 20 million $/ \mathrm{ml}$ or less. ${ }^{19}$ Cases were defined as those men who had oligozoospermia in both samples when two semen samples were tested and in the single sample when only one sample was available. Men without a semen result were not included in this part of the study analysis. The effects of exposure on sperm motility and morphology were also examined. Asthenozoospermia was defined as having $50 \%$ or less motile sperm in all samples tested. ${ }^{19} \mathrm{~A}$ high percentage of deformed sperm, teratozoospermia, was defined as having $70 \%$ or greater deformed sperm in all samples tested. ${ }^{19}$

The calculation of sample size for the study was based on the second arm of the analysis. The prevalence of leatherwork in the general population of men of reproductive age was estimated as $13 / 1000$ men. The calculation of sample size indicated that for the analysis based on oligozoospermia to have $90 \%$ power to detect a relative risk of 3.0 at the $5 \%$ level of significance, the comparison would need to be based on 1000 cases and 1000 controls. ${ }^{24}$ As pilot work had indicated that the split of oligozoospermia to a normal sperm concentration was 50:50, the target sample size for interview was 2000 men.

\section{ANALYSIS}

Binary outcome analysis

Unadjusted odds ratios (ORs) were estimated with $95 \%$ confidence intervals (95\% CIs) and adjusted ORs were estimated with unconditional logistic regression. ${ }^{25}$ All potential confounding variables were included as categorical or binary terms in the regression model containing the outcome (case or control) and explanatory variable of interest (occupational exposure). The conventional likelihood ratio test was used to assess whether terms could be removed from the model - that is, twice the change in log likelihood was compared with the $\chi^{2}$ distribution on the change in degrees of freedom commensurate with the term removed on each occasion. The terms were removed in ascending order of the likelihood ratio test and all terms that did not represent a significant $(p<0.05)$ component of the model were removed. The need for interaction terms was then assessed. The confounders considered were: illnesses possibly causing infertility; operations potentially affecting fertility; medicines or drugs potentially affecting fertility; exposure to $x$ radiation; alcohol consumption; caffeine intake; smoking; whether they were currently working or not; social class; age; marital status; working pattern; fixed (or not) place of work; use of cleaning agents; use of solvents; use of paints; use of colour mixing solutions; and use of welding equipment. The operations we considered as potentially affecting fertility were: operations for testicular 
Table 1 Demographic characteristics of the participants of the male infertility study $(n=1906)$

\begin{tabular}{|c|c|c|}
\hline Characteristics & $n$ & $\%$ \\
\hline \multicolumn{3}{|l|}{ Age (y): } \\
\hline Range & $18-65$ & \\
\hline Mean & 31.4 & \\
\hline SD & 5.96 & \\
\hline$\%$ Aged $20-44$ & & 96.7 \\
\hline \multicolumn{3}{|l|}{ Marital status: } \\
\hline Married & 1590 & 83.4 \\
\hline Living together & 300 & 15.7 \\
\hline Not living together & 16 & 0.9 \\
\hline \multicolumn{3}{|l|}{ Place of birth: } \\
\hline United Kingdom & 1520 & 79.7 \\
\hline Africa & 193 & 10.1 \\
\hline India, Pakistan, and Bangladesh & 118 & 6.2 \\
\hline Elsewhere & 75 & 4.0 \\
\hline \multicolumn{3}{|l|}{ Current employment: } \\
\hline Working & 1747 & 91.7 \\
\hline Unemployed & 143 & 7.5 \\
\hline Student & 12 & 0.6 \\
\hline Retired & 4 & 0.2 \\
\hline \multicolumn{3}{|l|}{ Area of residence ${ }^{\star}$ : } \\
\hline Leicestershire & 1606 & 83.4 \\
\hline Northamptonshire & 259 & 13.6 \\
\hline Elsewhere & 41 & 2.2 \\
\hline \multicolumn{3}{|l|}{ Social class (1980 classification $)^{21}$ : } \\
\hline I & 135 & 7.1 \\
\hline II & 435 & 22.8 \\
\hline IIIN & 193 & 10.1 \\
\hline IIIM & 758 & 39.8 \\
\hline IV & 322 & 16.9 \\
\hline V & 48 & 2.5 \\
\hline Armed forces and students & 12 & 0.6 \\
\hline Never worked & 3 & 0.2 \\
\hline
\end{tabular}

${ }^{\star}$ Residence defined on the basis of postcode and address.

adenoma and testicular torsion; prostatectomy; bladder lesion excision; bowel excision or resection; colectomy; inguinal hernia repair; hydrocoele excision; orchidopexy (unilateral or bilateral); unilateral orchidectomy; renal transplant; and varicocele excision.

\section{Continuous outcome analysis}

The values of the results from the semen analysis were compared by occupational exposure group. Because individual men had multiple semen samples multilevel modelling was used to estimate the change in sperm concentration, motility, and deformity associated with exposure, having adjusted for the effects of other factors of interest. ${ }^{26}$ For the analysis of the skewed sperm concentration data a $\log _{\mathrm{e}}$ $(+1)$ transformation was used to normalise the data. The motility and morphology data were near normal and did not require transformation. The level 1 residuals were checked and found to be approximately normally distributed for all three parameters.

Statistical inference

Like most epidemiological investigations, our study was not large enough to estimate small effects with high precision. Thus, 95\% CIs

Table 2 Comparison of the men from couples presenting with infertility (cases, $n=1606$ ). with the perinatal controls $(n=1013)$ for exposure to leatherwork and work with solvents in the current (or most recent) job; Leicestershire residents only

\begin{tabular}{|c|c|c|c|c|c|c|c|}
\hline \multirow[b]{2}{*}{ Exposure } & \multicolumn{2}{|l|}{ Cases } & \multicolumn{2}{|c|}{ Controls } & \multirow[b]{2}{*}{$O R$} & \multirow[b]{2}{*}{$95 \% C I$} & \multirow[b]{2}{*}{$p$ Value } \\
\hline & $n$ & $\%$ & $n$ & $\%$ & & & \\
\hline \multicolumn{8}{|c|}{ Leatherwork: } \\
\hline No & 1592 & 99.1 & 1005 & 99.2 & $1^{\star}$ & & \\
\hline Yes & 14 & 0.87 & 8 & 0.79 & 1.10 & 0.46 to 2.63 & 0.99 \\
\hline \multicolumn{8}{|c|}{ Work with solvents: } \\
\hline No & 1458 & 90.8 & 957 & 94.5 & $1^{\star}$ & & \\
\hline Yes & 148 & 9.2 & 56 & 5.5 & 1.73 & 1.26 to 2.38 & $<0.001$ \\
\hline
\end{tabular}

were often relatively wide and included regions of clinically relevant increased and decreased risk or no effect. This presents an interpretational difficulty. To assist interpretation we used a simple Bayesian method described by Burton et al. ${ }^{27}{ }^{28}$ In effect we estimated the posterior probability that the true OR was 2.0 or greater. This particular threshold value (2.0) was chosen as it was thought to be an OR that would reflect an effect of clinically important magnitude worth observing. If the calculated probability is small it suggests that there is unlikely to be an aetiological effect of clinically relevant magnitude. These results are quoted as percentages to avoid confusion with $\mathrm{p}$ values derived from significance testing.

\section{Results}

Of the 2154 men from couples presenting with infertility eligible for inclusion during the study period 1906 were interviewed; a response of $88.5 \%$. The demographic characteristics of the study participants are given in table 1 .

As the Leicestershire resident participants $(n=1606)$ were derived from a geographically defined population their characteristics could be compared with 1991 Leicestershire census data. ${ }^{29}$ The main differences were that a greater proportion of the study participants were married compared with the general population of men aged $20-44(84.7 \% v 56.7 \%)$. Fewer of the study participants were born in the United Kingdom than the general population $(77.1 \%$ $v 90.9 \%$ ) and more were born in Africa or the Indian subcontinent $(18.8 \% v 5.9 \%)$.

In total there were 26 men who were current leatherworkers or were recently unemployed leatherworkers. One worked in a tannery; one worked in coat and jacket fabrication; two worked in handbag manufacture; and the remaining 22 worked in shoe manufacture. At the time of interview 22 were currently employed, one had been unemployed for 1 month, one for 4 months, one for 6 and one for 12 months. That is, they had all had relatively recent exposure to leatherwork. Four of the leatherworkers did not have a semen analysis result available. In total 71 men currently worked or had worked at some stage in the past as leatherworkers (ever leatherworker) and had at least one semen analysis result available.

Overall 153 men with semen results had a current (or most recent) occupation which fell into the category of work involving possible exposure to solvents (solvent work) and 285 men worked in these occupations either currently or at some stage in the past (ever solvent work).

COMPARISONS WITH CONTROLS FROM THE PERINATAL MORTALITY SURVEY

The cases for comparisons with the controls from the perinatal mortality survey were defined as all 1606 Leicestershire male residents in the infertility study population. The controls comprised the 1013 Leicestershire resident fathers of the perinatal mortality study controls born 1985-92 who did not have a history of infertility (table 2) 
Table 3 Adjusted ORs for oligozoospermia, asthenozoospermia, and teratozoospermia and leatherwork (current or most recent job) $(n=1580)$

\begin{tabular}{|c|c|c|c|}
\hline Exposure (yes v no) & $\begin{array}{l}\text { Adjustedt } \\
\text { OR }\end{array}$ & $95 \% C I$ & $p$ Value \\
\hline \multicolumn{4}{|l|}{ Oligozoospermia: } \\
\hline Leatherwork (current or most recent) & 1.20 & 0.43 to 3.33 & 0.73 \\
\hline Surgical operations $\star$ & 2.43 & 1.64 to 3.62 & $<0.001$ \\
\hline Social class III: rest & 1.35 & 1.07 to 1.71 & 0.013 \\
\hline Leicestershire resident & 2.02 & 1.37 to 2.96 & $<0.001$ \\
\hline \multicolumn{4}{|l|}{ Asthenozoospermia: } \\
\hline Leatherwork (current or most recent) & 0.46 & 0.17 to 1.28 & 0.14 \\
\hline Surgical operations ${ }^{\star}$ & 2.02 & 1.37 to 2.99 & $<0.001$ \\
\hline Leicestershire resident & 2.15 & 1.59 to 2.91 & $<0.001$ \\
\hline \multicolumn{4}{|l|}{ Teratozoospermia: } \\
\hline Leatherwork (current or most recent) & 1.65 & 0.37 to 7.30 & 0.51 \\
\hline Surgical operations $\star$ & 2.20 & 1.23 to 3.93 & 0.008 \\
\hline Social class III: rest & 0.89 & 0.60 to 1.31 & 0.55 \\
\hline Leicestershire resident & 1.13 & 0.64 to 1.99 & 0.67 \\
\hline
\end{tabular}

* Surgical operations which may potentially impair fertility.

†Each OR listed for each subheading was adjusted for the effects of all other factors listed under that subheading.
The OR for the comparison between cases and controls for exposure to current (most recent) leatherwork was 1.10 (95\% CI 0.46 to $2.63 ; \mathrm{p}=0.99)$; this was not significant. The OR for current (most recent) work with solvents was 1.73 (95\% CI 1.26 to 2.38 ; $\mathrm{p}<0.001)$. This suggests that there was a significant $70 \%$ excess risk of presenting for the investigation of infertility associated with work with solvents.

CASE-CONTROL COMPARISONS WITHIN MEN FROM COUPLES PRESENTING WITH INFERTILITY

Leatherwork

These analyses were based on the 1580 male infertility study participants, regardless of place of residence, who had at least one semen sample tested. Of these, 367 were defined as cases with oligozoospermia and 1213 as controls without. Five $(1.35 \%)$ of the cases were leatherworkers in their current (or most recent) job, as were $17(1.4 \%)$ of the controls (unadjusted OR $0.97 ; 95 \%$ CI 0.36 to $2.65 ; \mathrm{p}=0.84)$. The adjusted ORs are given in table 3 .

Having adjusted for the factors listed compared with non-leatherworkers, leatherworkers were $20 \%$ (OR $1.20 ; 95 \%$ CI 0.43 to 3.33 ; $\mathrm{p}=0.73$ ) more likely to present with oligozoospermia. This result was not significant. The probability that the true relative risk was 2.0 or greater was $17 \%$. This indicates that there was less than a one in five chance that leatherwork leads to a twofold increase, or greater, in the risk of oligozoospermia.

Of the 1580 men included in the analysis $704(44.6 \%)$ had asthenozoospermia. Five of the $704(0.71 \%)$ with asthenozoospermia were leatherworkers as were 17 of the $876(1.94 \%)$ who had normal sperm motility (unadjusted OR 0.36 ; $95 \%$ CI 0.14 to $0.96 ; \mathrm{p}=0.046$ ). The adjusted OR was 0.46 (95\% CI 0.17 to 1.28 ; $\mathrm{p}=0.14$ ) and was not significant (table 3 ). There was only a $0.2 \%$ chance that the true relative risk of asthenozoospermia associated with leatherwork was 2.0 or greater.

Teratozoospermia was present in $108(6.8 \%)$ of the 1580 men with results and two $(1.85 \%)$ of these were leatherworkers. By comparison $20(1.36 \%)$ of those with normal levels of sperm deformity were leatherworkers (unadjusted OR $1.37 ; 95 \%$ CI 0.32 to $5.91 ; \mathrm{p}=0.99$ ). Table 3 shows that the adjusted OR was 1.65
Table 4 Semen characteristics for leatherworkers and non-leatherworkers (current or most recent job) $(n=1580)$

\begin{tabular}{lcc}
\hline Characteristics & Leatherworkers & Non-leatherworkers \\
\hline Sperm concentration $\left(\times 10^{6}\right.$ per ml): & \\
Men (n) & 22 & 1558 \\
Mean & 62.0 & 62.7 \\
SD & 59.7 & 63.7 \\
Median & 50.0 & 47.5 \\
Range & $0-239$ & $0-565$ \\
Sperm motility: & & \\
Men (n) & 22 & 1558 \\
Mean (\%) & 51 & 48 \\
SD (\%) & 23.5 & 22.2 \\
Median (\%) & 56 & 40 \\
Range (\%) & $0-92.5$ & $0-95$ \\
Sperm deformity: & & \\
Men (n) & 20 & 1560 \\
Mean (\%) & 35 & 39 \\
SD (\%) & 19.1 & 20.6 \\
Median (\%) & 37.5 & 38 \\
Range (\%) & $0-78.0$ & $0-98$ \\
& &
\end{tabular}

(95\% CI 0.37 to $7.30 ; p=0.51$ ), which suggests that leatherwork was associated with a $65 \%$ excess risk of teratozoospermia, although this result was not significant. There was a $43 \%$ chance that the true relative risk was 2.0 or greater and a $23 \%$ chance that it was 3.0 or greater.

Table 4 gives the results of the semen analysis comparing leatherworkers and nonleatherworkers. On the basis of these univariate results there was little evidence of a difference in sperm concentration, motility or deformity between the two groups.

The results of multilevel modelling indicated that having adjusted for the effects of surgical operations which may potentially impair fertility, social class, and place of residence, being a leatherworker was associated with only a $6 \%$ reduction ( $95 \%$ CI $-44 \%$ to $+59 \%$ ) in sperm concentration compared with not being a leatherworker. Having adjusted for the same factors, comparing leatherworkers with nonleatherworkers, there was an estimated increase in sperm motility of $0.78 \%(95 \%$ CI $-8.3 \%$ to $+9.9 \%$ ). Similarly, after adjustment there was a $0.84 \%$ reduction in sperm deformity $(95 \%$ CI $-9.4 \%$ to $+7.7 \%$ ).

Exposure to leatherwork at any stage in their career (ever leatherwork) was also investigated (table 5). Having adjusted for confounders, ever having been a leatherworker was associated with a non-significant $12 \%$ reduction (OR $0.88 ; 95 \%$ CI 0.48 to $1.60 ; \mathrm{p}=0.67)$ in the risk of oligozoospermia. There was only a $0.14 \%$ chance that ever being a leatherworker was associated with a true relative risk of 2.0 or greater. The results relating to the risk of asthenozoospermia and teratozoospermia were similar to those for oligozoospermia. Multilevel modelling results indicated that ever being a leatherworker was associated with a 7\% increase in sperm concentration $(95 \%$ CI $-21 \%$ to $+45 \%)$; a reduction in sperm motility of $1.3 \%(95 \%$ CI $-6.6 \%$ to $+3.9 \%)$; and an estimated increase in sperm deformity of $2.2 \%$ $(95 \% \mathrm{CI}-2.7 \%$ to $+7.0 \%)$.

Work with solvents

As can be seen from table 6 a current (or most recent) occupation involving work with solvents was associated with a $30 \%$ increase in the 
Table 5 Adjusted ORs for oligozoospermia, asthenozoospermia, and teratozoospermia and ever leatherwork with the probability of the true relative risk being $\geqslant 2.0$

\begin{tabular}{lllll}
\hline Exposure (yes v no) & Adjusted OR & $95 \%$ CI & p Value & $\begin{array}{l}\text { Probability that } \\
\text { the true RR is } \\
\geqslant 2.0\end{array}$ \\
\hline $\begin{array}{c}\text { Oligozoospermiał: } \\
\text { Ever leatherwork }\end{array}$ & 0.88 & 0.48 to 1.60 & 0.67 & $0.14 \%$ \\
$\begin{array}{c}\text { Asthenozoospermiał: } \\
\text { Ever leatherwork }\end{array}$ & 1.00 & 0.61 to 1.64 & 0.99 & $0.3 \%$ \\
$\begin{array}{c}\text { TeratozoospermiaS: } \\
\text { Ever leatherwork }\end{array}$ & 0.88 & 0.32 to 2.45 & 0.81 & $7 \%$
\end{tabular}

${ }^{\star}$ Adjusted for surgical operations which may potentially impair fertility, social class, and Leicestershire residence.

tCases $=$ oligozoospermia, $n=367$; controls $=$ not oligozoospermia, $n=1213$.

$\ddagger$ Cases $=$ asthenzoospermia, $\mathrm{n}=704$; controls $=$ not asthenozoospermia, $\mathrm{n}=876$.

\Cases=teratozoospermia, $\mathrm{n}=108$; controls=not teratozoospermia, $\mathrm{n}=1472$.

Table 6 Adjusted ORs for oligozoospermia, asthenozoospermia, and teratozoospermia and current (most recent) work with solvents and ever work with solvents; with the probability of the true relative risk ( $R R$ ) being $\geqslant 2.0$

\begin{tabular}{|c|c|c|c|c|}
\hline Exposure (yes v no) & $O R$ & $95 \% C I$ & $p$ Value & $\begin{array}{l}\text { Probability that } \\
\text { the true RR is } \\
\geqslant 2.0(n)\end{array}$ \\
\hline \multicolumn{5}{|l|}{ Oligozoospermia†: } \\
\hline Solvent work ${ }^{\star}$ & 1.33 & 0.91 to 1.95 & 0.14 & $1.5 \%$ \\
\hline Ever solvent work ${ }^{\star}$ & 1.20 & 0.91 to 1.78 & 0.23 & $0.03 \%$ \\
\hline \multicolumn{5}{|l|}{ Asthenozoospermiał: } \\
\hline Solvent work ${ }^{\star}$ & 1.14 & 0.81 to 1.61 & 0.44 & $0.1 \%$ \\
\hline Ever solvent work ${ }^{\star}$ & 1.22 & 0.94 to 1.58 & 0.14 & $0.0 \%$ \\
\hline \multicolumn{5}{|l|}{ Teratozoospermia $\$:$} \\
\hline Solvent work ${ }^{\star}$ & 1.14 & 0.60 to 2.17 & 0.71 & $5.1 \%$ \\
\hline Ever solvent work ${ }^{\star}$ & 1.17 & 0.71 to 1.92 & 0.51 & $2.3 \%$ \\
\hline
\end{tabular}

*Adjusted for surgical operations which may potentially impair fertility, social class, and Leicestershire residence.

†Cases $=$ oligozoospermia, $n=367$; controls $=$ not oligozoospermia, $n=1213$.

$\ddagger$ Cases $=$ asthenozoospermia, $n=704$; controls $=$ not asthenozoospermia, $n=872$.

\Cases=teratozoospermia, $n=108$; controls $=$ not teratozoospermia, $n=1451$.

risk of oligozoospermia; a $14 \%$ increase in the risk of asthenozoospermia; and a $14 \%$ increase in the risk of teratozoospermia. None of these results were significant and it was highly improbable that the true relative risk associated with any of these outcomes was 2.0 or greater. By definition the solvent worker group included leatherworkers; excluding these men had no material effect on the results. The adjusted multilevel modelling results showed that compared with non-solvent workers, solvent workers experienced an $8.0 \%$ reduction $(95 \%$ CI $-25 \%$ to $+15 \%)$ in sperm concentration; a $1.4 \%$ reduction (95\% CI $-5.0 \%$ to $+2.3 \%$ ) in sperm motility; and a $0.4 \%$ increase $(95 \% \mathrm{CI}-3.1 \%$ to $+3.8 \%)$ in sperm deformity. Table 6 shows that the results relating to ever having worked with solvents were similar to the results for current (or most recent) work.

The adjusted results from the multilevel modelling showed that compared with never solvent workers, ever solvent workers experienced a $1.0 \%$ reduction $(95 \%$ CI $-16 \%$ to $+17 \%$ ) in sperm concentration; a $1.6 \%$ reduction $(95 \%$ CI $-4.5 \%$ to $+1.3 \%)$ in sperm motility; and a $1.2 \%$ increase $(95 \%$ CI $-1.5 \%$ to $+3.9 \%$ ) in sperm deformity.

\section{Discussion}

LEATHERWORK

The results of this large case-control comparison with fertile controls suggest that men employed as leatherworkers are not at an increased risk of presenting, with their partner, for the investigation of infertility. We have two caveats to this conclusion. Firstly, the effects of confounders were not adjusted for. However, given the minimal effect of confounding found in those analyses in which we were able to make adjustments it seems likely that such an adjustment would have made little material difference to our inferences. Our second caveat is that as factors related to the decision to seek medical care may be associated with occupation the use of only men from infertile couples as cases, without including those who did not present for medical care, may have led to case selection bias. The effects of this potential bias would be to shrink the OR estimate towards the null.

Although there is a possibility that leatherwork was associated with an increase in the risk of oligozoospermia, this possibility was very small indeed. The results of this study clearly show the difficulty of concluding, with certainty, that there is no increase in the risk of a disease associated with an exposure. However, the Bayesian method described by Burton et $a l^{27}{ }^{28}$ is helpful in that it allows the estimation of the chance that the true value of an OR exceeds a certain threshold value which is chosen as one being of clinical importance. In the case of the result associated with oligozoospermia there was only a $17 \%$ chance that the true OR was 2.0 or greater. In other words, although this possibility cannot be formally excluded, the odds in favour of a lesser effect are greater than $4: 1$.

The findings relating to the risk of teratozoospermia was the only one of concern in relation to leatherwork. Although not significant the result suggests that leatherworkers may be at a $65 \%$ increased risk of teratozoospermia compared with other men. Furthermore, the Bayesian analysis indicated that there was a $43 \%$ chance that the true OR was 2.0 or greater. By contrast, the analysis based on the actual values from the semen analysis did not indicate a difference between leatherworkers and other men in the mean or median values for the proportion of deformed sperm. Interestingly, by contrast, Bigelow et $a^{\beta^{3}}$ detected differences in semen parameters analysed as continuous variables associated with particular workplace exposures which were not identified in a binary outcome analysis; leatherwork was not one of these exposures. However, in the absence of an important increase in the risk of presenting with infertility the evidence relating to teratozoospermia is not compelling, although it probably merits further investigation. Furthermore, if leatherwork is a risk factor for teratozoospermia, exposure to solvents does not seem to be the explanation for this. Overall, our findings should provide reassurance to the leatherworkers who use leather in manufacturing. Nothing can be concluded from these data about any potential risks related to tanning.

\section{WORK WITH SOLVENTS}

Work in the boot and shoe and leather goods industry is associated with exposure to a wide range of organic solvents. ${ }^{31}$ Animal work has shown adverse effects of glycol ethers on the reproductive function of many species. ${ }^{32}$ These effects include "microscopic testicular lesions, 
testicular atrophy, reduced numbers of late maturation-stage cells, and infertility." ${ }^{32}$ In particular testicular histology was found to correlate with abnormal sperm morphology.

We investigated the effects of work with solvents on male reproductive function, as we postulated at the outset that if there was an increased risk of oligospermia associated with leatherwork this would be mediated through exposure to solvents. Our results indicate that men currently working in occupations associated with exposure to solvents had a modest $(73 \%)$, but clinically relevant and significant increased risk of presenting for investigation of infertility. We were, however, unable to adjust this result for the effects of potential confounders and differential reporting between the cases and controls may have led to an overestimate of the OR. By contrast, our other results strongly suggest that work involving exposure to solvents is not a risk factor for oligozoospermia, asthenozoospermia, or teratozoospermia.

The evidence in the scientific literature of the possible effects of organic solvents on male fertility is inconsistent. Sallmén et $a^{\beta^{3}}$ and Eskenazi et $a l^{34}$ found a small but nonsignificant decrease in fecundability associated with use of tetrachloroethylene. In the same study Eskenazi et $a b^{34}$ found some effects on sperm morphology for dry cleaners but no effect on other sperm parameters. Compared with agricultural and cement workers, Danish painters were found to have an increased risk of infertility. ${ }^{35}$ By contrast Sallmén et al found little evidence of an effect on time to pregnancy for painters. ${ }^{33}$

Our finding of an increase in the risk of male infertility associated with occupations involving solvents taken as a group is in keeping with the overall findings of Sallmén et al. ${ }^{33}$ They found some evidence, although the role of chance was not excluded, that paternal exposure to organic solvents is associated with decreased fertility as assessed in a retrospective time to pregnancy study in which all couples conceived at least once.

The effects of solvents on sperm quality have also been investigated, again with some inconsistent and inconclusive findings. Welch et $a l^{\beta 6}$ found that compared with controls, painters were nearly three times more likely to have oligospermia and Ratcliffe $e t a l^{37}$ found that metal cast workers were at nearly a twofold increased risk of oligospermia. Neither of these results was significant and cigarette smoking was the only confounder adjusted for. Veulemans $e t a l^{\beta 8}$ described similar findings. Chia et $a^{\beta 9}$ reported that sperm density was lower in employees in the electronics industry who were exposed to high concentrations of trichloroethylene; whereas in a smaller study, Rasmussen et $a l^{40}$ found no effect on semen parameters for metal degreasers exposed to trichloroethylene. Plastics workers exposed to styrene were found to have an increase in the number of abnormal sperm. ${ }^{41}$

In our study a wide range of occupations with possible exposure to solvents was investigated. Exposure misclassification is likely to have occurred and there was a combination of occu- pations with high and low levels of exposure. Indeed, job title as used in this study has been criticised as an imprecise measure of exposure to specific agents in the workplace, ${ }^{42}$ although other investigators advocate this approach. ${ }^{434}$ Thus, although a relation was not found between those occupations defined in this study as work with solvents and abnormal semen findings, the possibility remains that this was a false negative finding resulting from misclassification. Indeed, the finding that work with solvents may increase the risk of presenting with infertility supports the view that we simply failed to detect the mechanism by which exposure to solvents operates to adverse effect and further investigation is recommended to clarify this issue.

\section{Conclusions}

There was little evidence to support the hypotheses that leatherwork is associated either with an increased risk of presenting with infertility or oligospermia. Overall, these findings are reassuring for workers who use leather in manufacturing. There is some, although far from compelling, evidence that leatherwork may be a risk factor for teratozoospermia. Although workers with solvents seemed to be at an increased risk of presenting with infertility, this did not seem to be mediated through direct effects on semen quality as measured in standard semen analysis tests.

We thank the Health and Safety Executive who funded this study and the Wellcome Trust who provided the research training fellowship for JJK. The analysis was finally completed while JJK was funded by the Australian National Health and Medical Research Council (grant 96/3209). We also thank the study
Reas funded by the Australian National Health and Medical interviewers Lesley Parr, Sue Pittam, Linda Jones, Anne Peel, interviewers Lesley Parr, Sue Pittam, Linda Jones, Anne Peel, go to the study subjects, who generously agreed to participate; go to the study subjects, who generously agreed to participate;
the clinic and consultant staff who facilitated our access to patients; and Elizabeth Draper who provided access to the perinatal mortality study control data.

\section{Appendix: Office of Populations,} Censuses and Surveys (OPCS) codes

(1) Codes defining leatherwork using the 1970 OPCS classification of occupation ${ }^{20}$

061 Shoemakers and shoe repairers

062 Cutters, lasters, sewers, footwear and related workers

063 Leather products makers nec*

(2) Codes defining work with solvents using the 1970 OPCS classification of occupation ${ }^{20}$

012 Chemical production process workers nec ${ }^{\star}$

061 Shoemakers and shoe repairers

062 Cutters, lasters, sewers, footwear and related workers

063 Leather products makers nec ${ }^{\star}$

070 Dyers of textiles

071 Textile fabrics and related products makers and examiners nec*

087 Printers (so described)

088 Printing workers nec*

089 Workers in rubber

090 Workers in plastics

099 Aerographers, paint sprayers

100 Painters, decorators nec ${ }^{\star}$

101 Coach painters (so described)

204 Chemists $\dagger$

219 Laboratory assistants, technicians

(3) Codes defining leatherwork using the 1980 OPCS classification of occupation ${ }^{21}$

08401 Foremen: Tannery production workers

08402 Foremen: Shoe repairers

08403 Foremen: Leather cutters and sewers, footwear lasters, makers, finishers

08404 Foremen: Other making and repairing, leather 
08501 Workers: Tannery production workers 08502 Workers: Shoe repairers

08503 Workers: Leather cutters and sewers, footwear lasters, makers, finishers

10707 All others in making and repairing leather

(4) Codes defining work with solvents using the 1980

OPCS classification of occupation ${ }^{21}$

08401 Foremen: Tannery production workers

08402 Foremen: Shoe repairers

08403 Foremen: Leather cutters and sewers, footwear lasters, makers, finishers

08404 Foremen: Other making and repairing, leather

08501 Workers: Tannery production workers

08502 Workers: Shoe repairers

08503 Workers: Leather cutters and sewers, footwear lasters, makers, finishers

10707 All others in making and repairing leather

16002 General labourers: Chemical and allied trades

15902 Foremen: Chemical and allied trades

13801 Laboratory assistants

13804 Inspectors, viewers, examiners: Rubber goods

13805 Inspectors, viewers, examiners: Plastic goods

13807 Inspectors, sorters in paper production, processing and printing

13808 Assemblers in paper production, processing and printing

13809 Assemblers (plastic goods)

13604 Foremen: Rubber goods

13605 Foremen: Plastic goods

13405 Foremen: Assemblers - plastic goods

13404 Foremen: Assemblers - paper production, processing and printing

13301 Painters, decorators, french polishers - pottery decorators

13302 Painters, decorators, french polishers - coach painters (so described)

13303 Painters, decorators, french polishers - other paint sprayers

13304 Painters, decorators, french polishers - painters and decorators nec ${ }^{\star}$, french polishers

13201 Foremen: Pottery decorators

13202 Foremen: Coach painters (so described)

13203 Foremen: Other paint sprayers

13204 Foremen: Painters and decorators nec ${ }^{\star}$, french polishers

10709 All others in making and repairing - paper goods and printing

10710 All others in making and repairing - rubber

10711 All others in making and repairing - plastic

10001 Painting workers, screen and block printers compositors

10002 Painting workers, screen and block printers electrotypers, stereotypers, printing plate and cylinder preparers

10003 Painting workers, screen and block printers printing machine minders and assistants

10004 Painting workers, screen and block printers screen and block printers

10005 Painting workers, screen and block printers printers (so described)

09901 Foremen - printing - compositors

09902 Foremen - printing - electrotypers, stereotypers, printing plate and cylinder preparers

09903 Foremen - printing - printing machine minders and assistants

09904 Foremen - printing - screen and block printers 09905 Foremen - printing - printers (so described) 09701 Rubber process workers, moulding machine operators, tyre builders

09702 Calender and extruding machine operators, moulders (plastics)

09509 Foremen - rubber

09510 Foremen - plastics

09504 Foremen - rubber process workers, moulding machine operators, tyre builders

09305 Foremen - other making and repairing, paper goods and printing

08900 Chemical, gas and petroleum process plant operators

08800 Foremen - chemical processing

08707 Textile workers - bleachers, dyers, finishers
08607 Foremen - bleachers, dyers, finishers

07503 Launderers, dry cleaners, pressers

05503 Sales assistants - petrol pump, forecourt attendants

05402 Sales supervisor - petrol pump, forecourt attendants

02801 Chemical engineers

02402 Chemical scientists

${ }^{\star}$ nec: not elsewhere classified

†Chemists not pharmacists

1 Battista G, Comba P, Orsi D, et al. Nasal cancer in leather workers: an occupational disease [editorial]. $\mathcal{F}$ Cancer Res Clin Oncol 1995;121:1-6.

2 Pirastu R, Iavarone I, Comba P. Bladder cancer: a selected review of the epidemiological literature [review]. Annali dell Istituto Superiore di Sanita 1996;32:3-20.

3 Garabrant DH, Wegman DH. Cancer mortality among shoe and leather workers in Massachusetts. Am F Ind Med 1984; 5:303-14.

4 Coggon D, Pannett B, Osmond C, et al. A survey of cancer and occupation in young and middle aged men. I. Cancers of the respiratory tract. Br f Ind Med 1986;43:332-8.

5 Knight JA, Marrett LD, Weir HK. Occupation and risk of germ cell testicular cancer by histological type in Ontario. $\mathcal{F}$ germ cell testicular cancer by histologica

6 Marshall EG, Melius JM, London MA, et al. Investigation of a testicular cancer cluster using a case-control approach. Int F Epidemiol 1990;19:269-73.

7 Walrath J, Decoufle P, Thomas TL. Mortality among workers in a shoe manufacturing company. Am f Ind Med 1987; 12:615-23.

8 Scherr PA, Hutchison GB, Neiman RS. Non-Hodgkin's ymphoma and occupational exposure. Cancer Res 1992; 52(suppl 19):S5503-9.

9 Fu H, Demers PA, Costantini AS, et al. Cancer mortality among shoe manufacturing workers: an analysis of two cohorts. Occup Environ Med 1996;53:394-8.

10 Clarke M, Mason ES. Leatherwork: a possible hazard to reproduction. BMF 1985;290:1235-7.

11 McDonald AD, McDonald JC. Outcome of pregnancy in leatherworkers. BMF 1986;292:979-81.

12 McDonald AD, McDonald JC, Armstrong B, et al. Fetal death and work in pregnancy. Br f Ind Med 1988;45:14857

13 Clarke M, Mason ES. Shoe manufacture and possible hazard to reproduction. BMF 1988;296:466.

14 Sallmen M, Lindbohm ML, Kyyronen P, et al. Reduced fertility among women exposed to organic solvents. Am f Ind Med 1995;27:699-713.

15 Agnesi R, Valentini F, Mastrangelo G. Risk of spontaneous abortion and maternal exposure to organic solvents in the shoe industry. Int Arch Occup Environ Health 1997;69:31116.

16 Sanjose S, Roman E, Beral V. Low birth weight and preterm delivery, Scotland, 1981-4: effect of parents' occupation. Lancet 1991;338:428-31.

17 Bianchi F, Cianciulli D, Pierini A, et al. Congenital malformations and maternal occupation: a registry based case-control study. Occup Environ Med 1997;54:223-8.

18 Garcia AM, Fletcher T. Maternal occupation in the leather industry and selected congenital malformations. Occup industry and selected cong
Environ Med 1998;55:284-6.

19 World Health Organisation. WHO laboratory manual for the examination of human semen and semen-cervical mucus interaction. Cambridge: Cambridge University Press, 1987.

20 Office of Populations, Censuses and Surveys. Classification of occupations 1970. London: The Stationery Office, 1970.

21 Office of Population Censuses and Surveys. Classification of occupations 1980. London: The Stationery Office, 1980.

22 Clarke $M$, Clayton $D$. The design and interpretation of case-control studies of perinatal mortality. Am f Epidemiol 1981;113:636-45

23 Clarke M, Clayton DG, Mason ES, et al. Asian mothers' risk factors for perinatal death - the same or different ? A 10 year review of Leicestershire perinatal deaths. BMF 1988;297:384-7.

24 Breslow NE, Day NE. Statistical methods in cancer research. Vol II - The design and analysis of cohort studies. Lyon: International Agency for Research on Cancer. 1987.

25 Clayton D, Hills M. Statistical models in epidemiology. Oxford: Oxford University Press, 1993.

26 Goldstein H. Multilevel modelling in education and social research. London: Charles Griffin, 1987.

27 Burton PR. Helping doctors to draw appropriate inferences from the analysis of medical studies. Stat Med 1994;13: 1699-713.

28 Burton PR, Gurrin LC, Campbell MJ. Clinical significance and not statistical significance: a simple Bayesian alternative to p values. F Epidemiol Community Health 1998;52: $318-23$.

29 Office of Population Censuses and Surveys. 1991 Census, County Report: Leicestershire (Part 1 and 2). London: The Stationery Office, 1992

30 Bigelow PL, Jarrell J, Young M, et al. Association of semen quality and occupational factors: comparison of casecontrol analysis and analysis of continuous variable. Fertil Steril 1998;69:11-18.

31 Scarpelli A, Miligi L, Costantini AS, et al. Exposure to solvents in the shoe and leather goods industries. Int $\mathcal{F}$ Epidemiol 1993;22(suppl 2):S46-50. 
32 Wess J. Reproductive toxicity of ethylene glycol monomethyl ether, ethylene glycol monoethyl ether and their acetates. 1 2):43-5.

33 Sallmén M, Lindbohm M-L, Anttila A, et al. Time to pregnancy among the wives of men exposed to organic solvents. Occup Environ Med 1998;55:24-30

34 Eskenazi B, Wyrobeck AJ, Fenster L, et al. A study on the effect of perchloroethylene exposure on semen quality in dry cleaning workers. Am F Ind Med 1991;20:575-91.

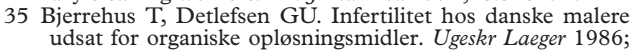
18:1105-6.

36 Welch LS, Schrader SM, Turner TW, et al. Effects of exposure to ethylene glycol ethers on shipyard painters: II. Male reproduction. Am f Ind Med 1988;14:509-26.

37 Ratcliffe JM, Schrader SM, Clapp DE, et al. Semen quality in workers exposed to 2-ethoxyethanol. BrF Ind Med 1989; 46:399-406.
38 Veulemans H, Steeno O, Masschelein R, et al. Exposure to ethylene glycol ethers and spermatogenic disorders in man: a case-control study Br F Ind Med 1993:50:71-8.

39 Chia SE, Ong CN, Tsakok MFH, et al. Semen parameters in workers exposed to trichloroethylene. Reprod Toxicol 1996;10:295-9.

0 Rasmussen K, Sabroe S, Wohlert M, et al. A genotoxic study of metal workers exposed to trichloroethylene. Sperm parameters and chromosome aberrations in lymphocytes. Int Arch Occup Environ Health 1988;60:419-23.

41 Jelnes JE. Semen quality in workers producing reinforced plastic. Reprod Toxicol 1988;2:209-12.

42 Sever LE. Editorial: male-mediated developmental toxicity. Epidemiology 1995;6:573-4.

43 Floderus B. Is job title an adequate surrogate to measure magnetic field exposure. Epidemiology 1996;7:115-6.

44 Kennedy SM. When is a disease occupational? Lancet 1994; 344:4-5.

\section{Vancouver style}

All manuscripts submitted to Occup Environ Med should conform to the uniform requirements for manuscripts submitted to biomedical journals (known as the Vancouver style.)

Occup Environ Med, together with many other international biomedical journals, has agreed to accept articles prepared in accordance with the Vancouver style. The style (described in full in the $\mathcal{F} A M A[1])$ is intended to standardise requirements for authors, and is the same as in this issue.

References should be numbered consecutively in the order in which they are first mentioned in the text by Arabic numerals on the line in square brackets on each occasion the reference is cited (Manson[1] confirmed other reports[2][3][4][5]). In future references to papers submitted to Occup Environ Med should include: the names of all authors if there are three or less or, if there are more, the first three followed by et al; the title of journal articles or book chapters; the titles of journals abbreviated according to the style of Index Medicus; and the first and final page numbers of the article or chapter. Titles not in Index Medicus should be given in full.

Examples of common forms of references are:

1 International Committee of Medical Journal Editors. Uniform requirements for manuscripts submitted to biomed journals. fAMA 1993;269:2282-6.

2 Soter NA, Wasserman SI, Austen KF. Cold urticaria: release into the circulation of histmaine and eosinophil chemotactic factor of anaphylaxis during cold challenge. N Engl f Med 1976;294:687-90.

3 Weinstein L, Swartz MN. Pathogenic properties of invading micro-organisms. In: Sodeman WA Jr, Sodeman WA, eds. Pathologic physiology, mechanisms of disease. Philadelphia: W B Saunders, 1974:457-72. 